\title{
A módosított „facial degloving” technikával szerzett hosszú távú tapasztalataink
}

\author{
Szalenko-Tőkés Ágnes dr. - Bella Zsolt dr. - Tóbiás Zoltán dr. \\ Iván László dr. - Rovó László dr. - Vass Gábor dr.
}

Szegedi Tudományegyetem, Általános Orvostudományi Kar, Fül-Orr-Gégészeti és Fej-Nyaksebészeti Klinika, Szeged

\begin{abstract}
Bevezetés: Az orrmelléküreg-daganatok kezelésében a legfrissebb nemzetközi ajánlások alapján továbbra is a sebészi reszekció az elsődlegesen választandó módszer. Bár az endoszkópos technikák fejlődésével a külső feltárással járó mütétek bizonyos esetekben háttérbe szorultak, napjainkban még mindig a Weber-Fergusson-féle metszést tartják a legszélesebb feltárást biztosító technikának, annak ellenére is, hogy a módszer stigmatizáló hegeket és deformitásokat hagy a páciensek arcán.

Módszer: A „facial degloving” eljárást mint alternatív, hegmentes technikát először az 1970-es években publikálták, azóta számos módosítását írták le. A szerzők az orrmelléküregi tumorok eltávolítására már 8 éve kizárólag az általuk módosított technikát alkalmazzák. 2012 és 2019 között Klinikánkon 34 beteg esett át a módosított „facial degloving” mútéten. A módszer alapja egy felső szájpitvari behatolásból a középarc területén kialakított oszteoplasztikus lebeny, melynek felemelésével széles rálátás nyílik az orrüregre és melléküregeire, valamint az elülső koponyaalapra is. A mútéti terület a daganat eltávolítását követően jó kozmetikai eredménnyel rekonstruálható.

Eredmények: A szerzők akusztikus rinometriai vizsgálatokkal és az arckifejezéseket ábrázoló posztoperatív képi dokumentációval támasztották alá eredményeiket. Az operált oldalon sem az orrbemenet beszúküulését (orrlégzés gátoltsága), sem pedig az arcmozgás zavarait, az arc aszimmetriáját nem észlelték. Betegeik túlélését Kaplan-Meier-görbén ábrázolták.

Megbeszélés, következtetés: Habár az eredeti „facial degloving” technikának számos módosítását publikálták, az itt bemutatott módszer (oszteoplasztikus lebeny, melyben a középarc lágy részeinek integritása megtartott) rövidebb hospitalizációs időt és kevesebb komplikációt eredményezett. A bemutatott módosított „facial degloving” technika véleményünk szerint megfelelő és biztonságos sebészi reszekciót biztosít orrmelléküregi rosszindulatú daganatok esetén, továbbá kombinálható endoszkópos technikákkal, és szükség esetén nyitott mútétté alakítható, akár orbitalis kiterjesztéssel.
\end{abstract}

Orv Hetil. 2021; 162(10): 392-398.

Kulcsszavak: arcüregi és orrmelléküregi tumorok, hegmentes megközelítés, módosított „facial degloving”, oszteoplasztikus lebeny

\section{Long-term experiences by using modified facial degloving technique}

Introduction: The widely used external approach (Weber-Fergusson's incision) for the removal of maxillo-ethmoidal tumors leaves stigmatizing scars and deformities on the patient's face. As an alternative technique, the scarless facial degloving approach was first described in the 1970's, and since then, several modifications have been developed.

Method: We have been using our modified facial degloving technique for eight years now with maxillo-ethmoidal tumors. Between 2012 and 2019, 34 consecutive patients have been operated with our modified facial degloving approach at the Department of Oto-Rhino-Laryngology and Head-Neck Surgery, University of Szeged, Hungary. We describe our method which provides a wide surgical approach via an osteoplastic flap for the whole nasal and paranasal region, with good cosmetic results.

Results and conclusion: We have evaluated our results with acoustic rhinometry and photo-documentation of the facial mimic postoperatively. Neither narrowing of the nasal cavity on the operated side (loss of nasal breathing function), nor facial movement dysfunction was visible in our patients. We represent our patients' survival in KaplanMeier curve. Although several modifications of the original facial degloving approach have been published, in our technique, the novel osteoplastic flap and the intact soft tissue of the nasal and midfacial region results in shorter 
hospitalization time and fewer complications. Our modified facial degloving technique offers proper and safe surgical resection for tumors of the maxillo-ethmoid region. It can be routinely combined with endoscopic techniques, and, if necessary, can be converted to an open approach.

Keywords: modified facial degloving, maxillo-ethmoidal tumors, osteoplastic flap, scarless approach

Szalenko-Tőkés Á, Bella Zs, Tóbiás Z, Iván L, Rovó L, Vass G. [Long-term experiences by using modified facial degloving technique]. Orv Hetil. 2021; 162(10): 392-398.

(Beérkezett: 2020. július 21.; elfogadva: 2020. augusztus 11.)

\section{Rövidítések}

$\mathrm{CT}=($ computed tomography) számítógépes tomográfia; MR $=($ magnetic resonance $)$ mágneses rezonancia

Az orrmelléküregi rosszindulatú és az agresszíven növekvő jóindulatú daganatok kezelésében a legfrissebb nemzetközi ajánlások alapján továbbra is a sebészi reszekció az elsődlegesen választandó módszer [1]. Posztoperatív sugárkezelés és a szövettani típustól függően kemoterápia minden esetben javasolt, tekintettel arra, hogy a speciális anatómiai viszonyok miatt kórszövettani R0-reszekcióról nem beszélhetünk, noha a daganat több részletben történő eltávolítása végeredményben ablatív [1]. Sebészi in toto eltávolítás csak nagyon korai stádiumú (T1, T2), kis kiterjedésű daganatoknál lenne elérhető, ezeket azonban Klinikánkon szinte kivétel nélkül endoszkópos mútéttel operáljuk, amelynél technikailag általában ugyancsak nem kivitelezhető az egy anyagban történő eltávolítás.

Bár az endoszkópos technikák fejlődésével a külső feltárással járó mútétek bizonyos esetekben háttérbe szorultak, napjainkban még mindig a transfacialis feltárást biztosító Weber-Fergusson-metszést - szükség szerint translabialis (Moore) és/vagy infraorbitalis (Dieffenbach) kiterjesztéssel - tartják a legszélesebb feltárást biztosító technikának, annak ellenére is, hogy ez a mútéti

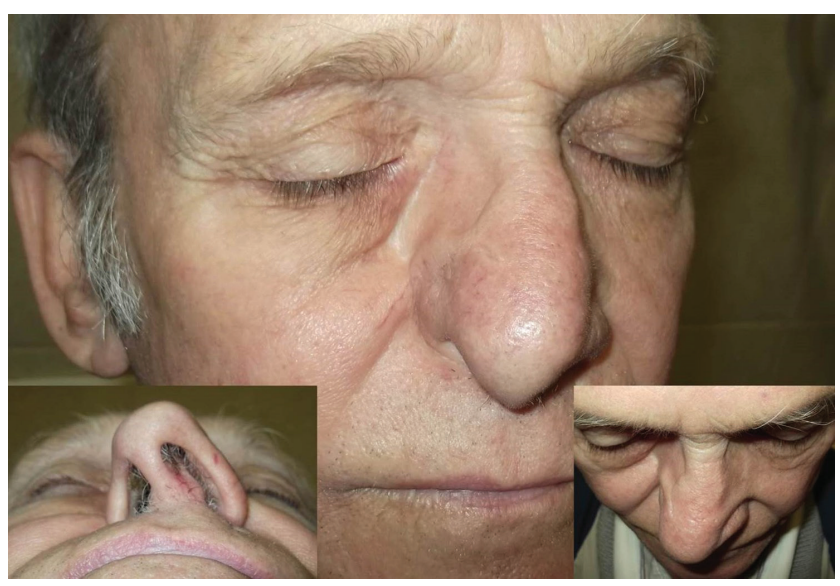

1. ábra

| Weber-Fergusson-féle metszés - mútét utáni képek megközelítés posztoperatív esztétikai arcdeformitásokat okozhat $[2,3]$ (1. ábra).

Ahhoz, hogy ezeket a következményeket elkerüljük, szükségessé vált egy olyan, rejtett metszéseken alapuló technika kidolgozása, amely ugyanazt a rálátást és hozzáférést biztosítja a tumorhoz, mint a fent említett klasszikus módszer. Ennek a megközelítésnek azonban a fó problémája az, hogy hogyan távolítsuk el a középarc és az orr teljes lágy szövetét ahhoz, hogy a teljes arcüregi és orrmelléküregi régióhoz hozzáférjünk.

A klasszikus Weber-Fergusson-féle nyitott technika során a bőrt és a lágy részeket csontig átvágjuk a paranasalis vonal és a felső ajak filtrumának mentén, így mobilizálva a lágy szöveteket. Conley és Price már rejtett megközelítést javasolt sublabialis, transfixiós és intercartilagin metszések segítségével, az úgynevezett klasszikus „facial degloving" technikát, melynek alkalmazásakor a középarc lágy részei megemelhetók voltak, limitált feltárás mellett [4]. Az eredeti módszer az orrkorrekciós mütétek során használt transfixiós és intercartilagin metszéseken alapul a szájpitvari incisio mellett, aminek következtében a mútéti feltárást egyrészt az apertura piriformis mérete limitálta, másrészt relatíve magas volt az orrbemeneti hegek okozta szúkület és a következményes orrlégzési elégtelenség szövődményi rátája [4]. A szerzők ezt a technikát módosították és használják több mint 8 éve az előrehaladott stádiumú orrmelléküregi daganatok mútétei során. Ennek a sebészi technikának a legfőbb előnye a jó esztétikai eredményeken túl a széles feltárás és a jó hozzáférhetőség a legkülönbözőbb lokalizációjú tumorokhoz [5].

\section{Betegek és módszer}

A Szegedi Tudományegyetem Fül-Orr-Gégészeti és FejNyaksebészeti Klinikáján 2012 és 2019 között 34, egymást követő beteg esett át a módosított „facial degloving” mütéten, 13 esetben endoszkópasszisztáltan. Klinikánkon a jóindulatú és a T1-, T2-stádiumú rosszindulatú daganatokat szinte minden esetben endoszkópos technikával operáljuk. A nyitott mútét indikációját az endoszkópos eltávolítás limitáltsága jelentette (orbitaérintettség, a praemaxillaris lágy szövetek vagy a bőr infiltráltsága, a tumorszövet jelentős laterális kiterjedése vagy a carotisrégió érintettsége stb.). 
A betegek átlagéletkora 64,2 év (19 és 70 év között) volt, nemi megoszlása: 21 nő (61\%) és 13 férfi (39\%). Összes betegünknél szövettanilag igazolt malignus arcüregi tumor állt fenn, továbbá a preoperatív tervezéshez és a folyamat kiterjedésének megítéléséhez koponya-CTés/vagy MR-vizsgálat készült. Betegeink adatait az 1 . táblázatban foglaltuk össze.

\section{A módosított „facial degloving” technika}

Általános anesztéziát követően a praemolaris fogak között a szájpitvar ívének megfelelő metszést ejtünk. Az incisio követi a porcos orrsövény elülső és szükség szerint a felső szélét (hasonlóan a transfixiós metszéshez), valamint az apertura piriformis alsó vízszintes vonalát (az orralapi nyálkahártya metszésvonala). Ahhoz, hogy minél szélesebb feltárást biztosítsunk, a módosított technika során oszteoplasztikus lebenyt alakítunk ki, orrplasztikai ívelt véső́ket használva. Az apertura piriformis legmélyebb laterális zugától kezdve, ahol a fentebb említett nyálkahártyametszés véget ér, vízszintes osteotomiát indítunk egyik vagy mindkét oldalra, melynek oldalirányú kiterjesztését a daganat elhelyezkedése szabja meg. Ezt egy felfelé irányuló, ívelt csontmetszésben folytatjuk a csontos orrpiramist megcélozva, amelyen a feltáráshoz szükséges egy- vagy kétoldali laterális osteotomiát a zárt orrplasztikai technikához hasonlóan, Cottle-féle raspatóriummal kialakított subperiostealis járatok mentén vé-

1. táblázat | Összefoglaló táblázat a 2012 és 2019 között módosított „facial degloving” technikával mútött 34 betegről

\begin{tabular}{|c|c|c|c|c|c|}
\hline Beteg & Életkor & $\mathrm{Nem}$ & Szövettan & Tumorstádium & Onkológiai kezelés \\
\hline 1. & 67 & Nó & Sarcoma & T3 & Sugárterápia + kemoterápia \\
\hline 2. & 42 & Férfi & Laphámsejtes carcinoma & $\mathrm{T} 2$ & Sugárterápia + kemoterápia \\
\hline 3. & 33 & Nő & Laphámsejtes carcinoma & T4a & Sugárterápia + kemoterápia \\
\hline 4. & 23 & Nö & Laphámsejtes carcinoma & $\mathrm{T} 2$ & Sugárterápia \\
\hline 5. & 51 & Férfi & Melanoma malignum & $\mathrm{T} 2$ & Sugárterápia \\
\hline 6. & 54 & Férfi & Laphámsejtes carcinoma & $\mathrm{T} 3$ & Sugárterápia + kemoterápia \\
\hline 7. & 19 & Nó & Olfactorius neuroblastoma & Stage $2 \mathrm{~b}$ & Sugárterápia \\
\hline 8. & 28 & Férfi & Adenocarcinoma & T3 & Sugárterápia \\
\hline 9. & 45 & Nó & Laphámsejtes carcinoma & T4a & Sugárterápia + kemoterápia \\
\hline 10. & 39 & Nó & Verrucosus carcinoma & $\mathrm{T} 2$ & Sugárterápia + kemoterápia \\
\hline 11. & 30 & Nő & Adenocarcinoma & $\mathrm{T} 2$ & Sugárterápia \\
\hline 12. & 44 & Nö & Laphámsejtes carcinoma & T3 & Sugárterápia + kemoterápia \\
\hline 13. & 56 & Férfi & Verrucosus carcinoma & $\mathrm{T} 2$ & Sugárterápia \\
\hline 14. & 65 & Férfi & Basalsejtes laphámcarcinoma & $\mathrm{T} 2$ & Sugárterápia + kemoterápia \\
\hline 15. & 34 & Nó & Haemangiopericytoma & Grade II. & Sugárterápia + kemoterápia \\
\hline 16. & 60 & Férfi & Laphámsejtes carcinoma & $\mathrm{T} 4 \mathrm{a}$ & Sugárterápia + kemoterápia \\
\hline 17. & 37 & Nó & Adenocarcinoma & $\mathrm{T} 3$ & Sugárterápia \\
\hline 18. & 48 & Nó & Verrucosus carcinoma & $\mathrm{T} 4 \mathrm{a}$ & Sugárterápia + kemoterápia \\
\hline 19. & 37 & Nő & Laphámsejtes carcinoma & T3 & Sugárterápia + kemoterápia \\
\hline 20. & 62 & Férfi & Melanoma malignum & $\mathrm{T} 2$ & Sugárterápia + kemoterápia \\
\hline 21. & 48 & Férfi & Laphámsejtes carcinoma & $\mathrm{T} 4 \mathrm{~b}$ & Sugárterápia + kemoterápia \\
\hline 22. & 42 & Nő & Laphámsejtes carcinoma & $\mathrm{T} 3$ & Sugárterápia + kemoterápia \\
\hline 23. & 57 & Nő & Laphámsejtes carcinoma & $\mathrm{T} 2$ & Sugárterápia + kemoterápia \\
\hline 24. & 42 & Nó & Verrucosus carcinoma & $\mathrm{T} 2$ & Sugárterápia \\
\hline 25. & 53 & Férfi & Laphámsejtes carcinoma & $\mathrm{T} 3$ & Sugárterápia + kemoterápia \\
\hline 26. & 61 & Nő & Adenocarcinoma & $\mathrm{T} 3$ & Sugárterápia \\
\hline 27. & 59 & Férfi & Melanoma malignum & $\mathrm{T} 2$ & Sugárterápia \\
\hline 28. & 38 & Nó & Laphámsejtes carcinoma & $\mathrm{T} 4 \mathrm{a}$ & Sugárterápia + kemoterápia \\
\hline 29. & 55 & Nó & Laphámsejtes carcinoma & $\mathrm{T} 2$ & Sugárterápia + kemoterápia \\
\hline 30. & 60 & Nó & Sarcoma & T3 & Sugárterápia \\
\hline 31. & 39 & Férfi & Laphámsejtes carcinoma & $\mathrm{T} 2$ & Sugárterápia + kemoterápia \\
\hline 32. & 54 & Nó & Laphámsejtes carcinoma & $\mathrm{T} 2$ & Sugárterápia + kemoterápia \\
\hline 33. & 64 & Férfi & Melanoma malignum & $\mathrm{T} 4 \mathrm{~b}$ & Sugárterápia + kemoterápia \\
\hline 34. & 70 & Nő & Laphámsejtes carcinoma & $\mathrm{T} 2$ & Sugárterápia \\
\hline
\end{tabular}




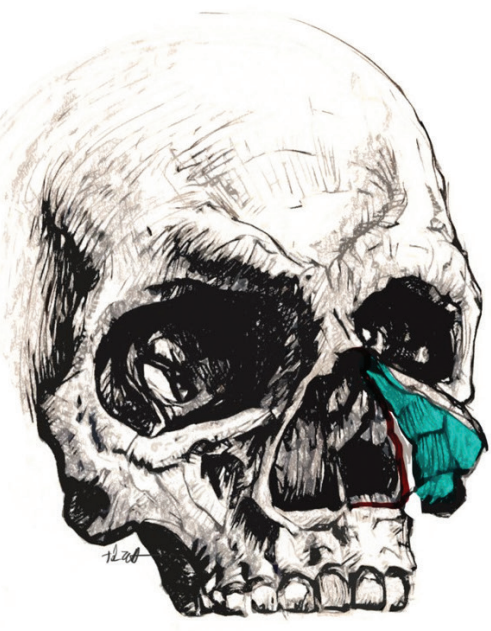

a)

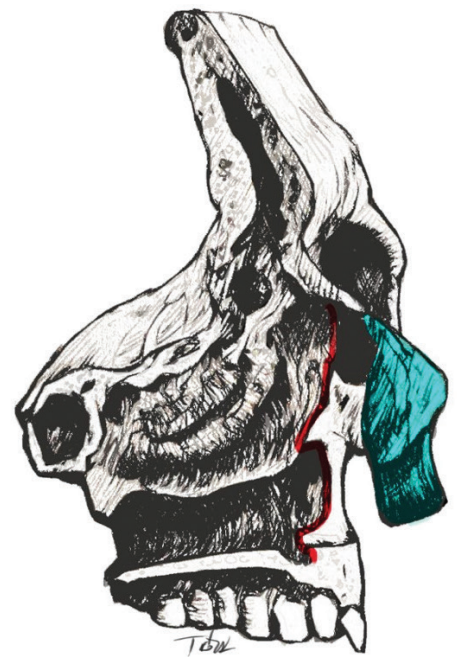

b)

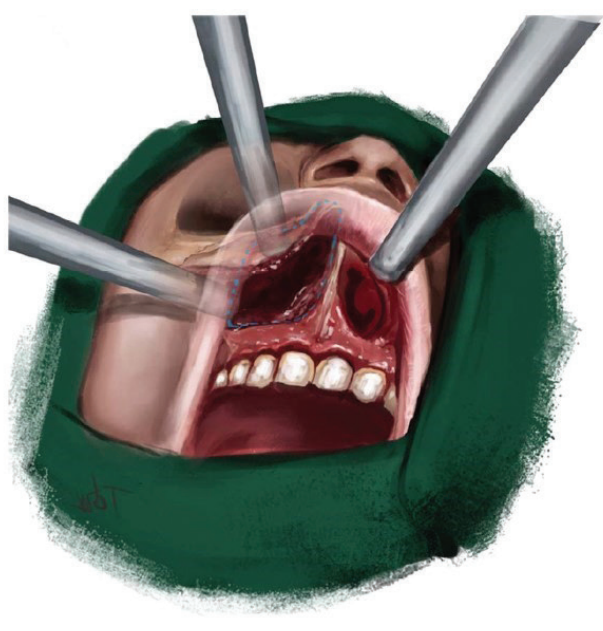

a)

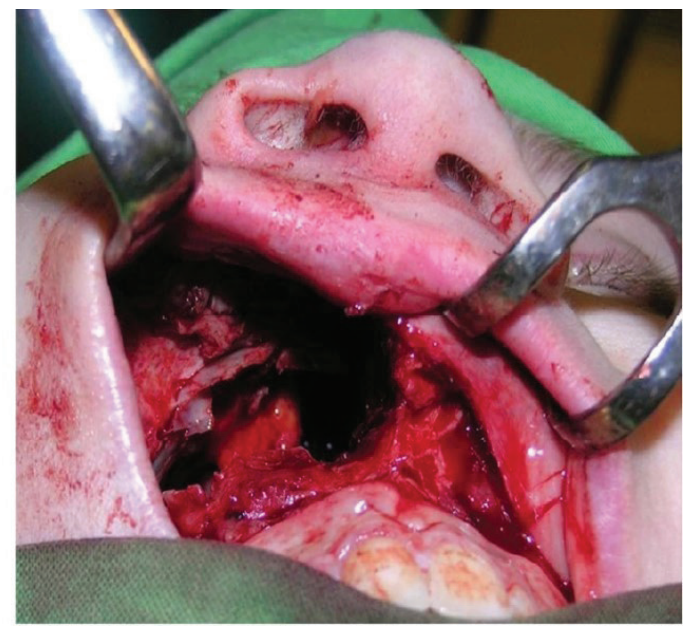

b)

3. ábra $\quad$ a) A mútéti feltárás (saját illusztráció) - jobb oldalon a felemelt oszteoplasztikus lebennyel (a metszésvonalakat kék pontozott vonallal jeleztük). b) A mútét során készült kép - jobb oldalon a felemelt oszteoplasztikus lebeny

gezzük el. A csontfelszínek feletti lágy részek integritása ily módon az osteotomiák vonalát kivéve érintetlen marad (oszteoplasztikus lebeny), és a porcos orrváz, valamint a középarc lágy részeinek rugalmasságát kihasználva a teljes középarc „degloving”-szerüen felemelhető, szemben az irodalomban leírt egyéb hasonló módosításokkal [6-9] (2. ábra).

Ezzel a feltárással a teljes orr- és orrmelléküreg-rendszer elérhetővé válik a koponyaalaptól az orrgaratig, teljes szélességében, és a tumor ablatív reszekciója könnyedén elvégezhető (3. ábra).

Tapasztalatunk szerint a teljes orrmelléküreg-rendszert javasolt feltárni a daganat kiterjedésétől függetlenül, részben a rejtett recidívák megelózésére, részben a posztoperatív endoszkópos utánkövetés megkönnyítésére [5]. Ha szükséges, endoszkóp vagy mikroszkóp segít- ségével ellenőrizhetjük és teljessé tehetjük a reszekciót, vagy kipreparálhatjuk és koagulálhatjuk az arteria sphenopalatinát és ethmoideát intraoperatív vérzéscsillapítás céljából [10]. Az orrsövényen az orralap mentén a szájpaddal párhuzamos metszést ejthetünk „swinging door” technikát alkalmazva, hogy a féloldali daganathoz jobban hozzáférjünk, de az orrsövény részlegesen el is távolítható tumoros beszűrtség esetén. A mưtét utolsó lépéseként az oszteoplasztikus lebenyt és a lágy részeket repozicionáljuk úgy, hogy a megmaradt könnycsatorna szabadon nyíljon az orrföüregbe [11]. Tumoros infiltráció miatt reszekált részleges infraorbitalis keret, arcüreg elülső csontos fal vagy orrcsonthiány esetén bordaporccal vagy lemezes osteosynthesissel lehet azonnali vagy akár halasztott rekonstrukciót végezni [12]. Mivel az érintett szövetek integritása megmarad az oszteoplaszti- 
kus lebeny kialakítása során, nincs szükség a csontok synthesisére (4/a és $4 / b$ ábra).

A sublabialis metszést felszívódó varratokkal zárjuk. A mütéti üreget 3-5 napig tamponáljuk, az orrot kívülról sínezzük. A betegek általában minimális posztoperatív fájdalomra panaszkodnak, lényeges diszkomfortot nem éreznek a tamponok miatt.

\section{Eredmények}

A posztoperatív eredményeket egyrészt akusztikus rinometria segítségével értékeltük, melynek során megmértük az orrüreg keresztmetszetét és térfogatát (dekongesztánst nem alkalmaztunk). A vizsgálat igazolta, hogy a mütét nem okoz orrbemeneti szúkületet vagy gátolt orrlégzést [5]. Másrészt fotódokumentáció segítségével rögzítettük a posztoperatív szakban az arc szimmetriáját és mimikai mozgásainak megtartottságát [5].

Betegeink túlélését Kaplan-Meier-görbén ábrázoltuk (5/a és 5/b ábra). A Kaplan-Meier-féle túlélési görbék elkésztéséhez SPSS Version 26 statisztikai programot (IBM Corporation, Armonk, NY, Amerikai Egyesült Államok) használtunk. Az összesített görbe alapján a vizsgált populáció $50 \%$-os túlélése 3 év. A nemek tekintetében $(5 / b$ ábra) szignifikáns különbséget találtunk, a nők relatíve jobb prognózist mutattak (50\%-os túlélés, 5 év), mint a férfiak (50\%-os túlélés, 3 év). Az 5 éves túlélés szintén a fenti nemi differenciát követi. A nemi különbség a túlélés tekintetében részben abból adódik, hogy a két csoportban eltérő a betegség stádiuma: a férficsoportban magasabb arányban szerepelnek előrehaladott T3-, T4a-esetek. A másik magyarázat a két csoportban

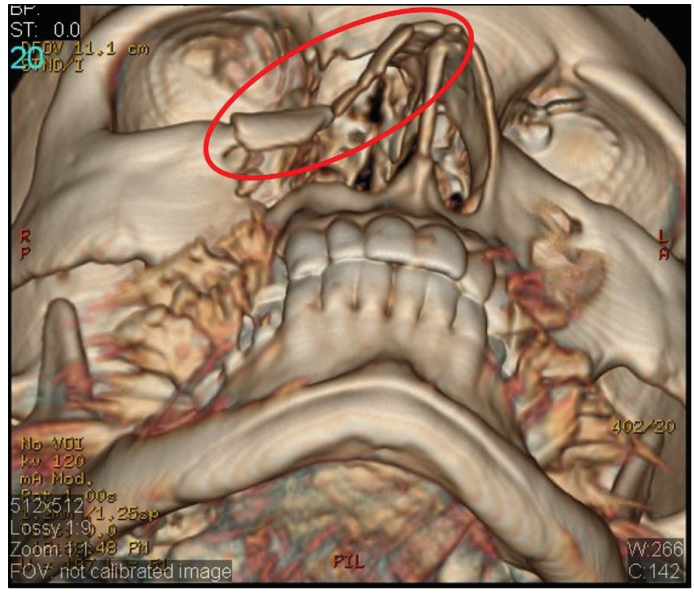

a)

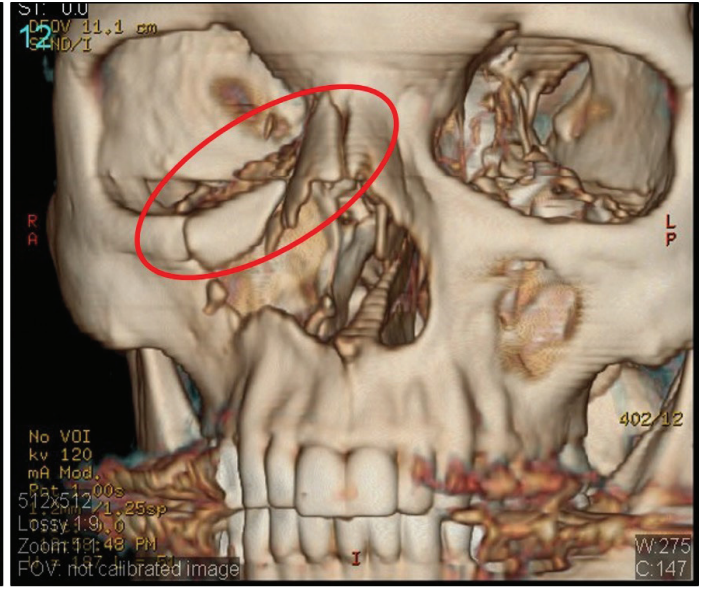

b)

4. ábra $\quad$ a) Axialis-ferde sík és b) frontalis-ferde sík: a mútét utáni 3D rekonstrukciós CT-felvétel csontablakkal. A visszahelyezett oszteoplasztikus lebenyt a piros ovális körvonallal jeleztük

CT = számítógépes tomográfia

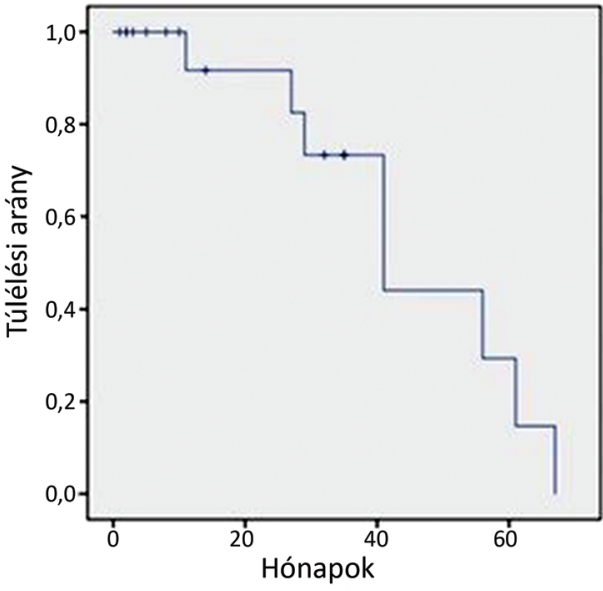

a)

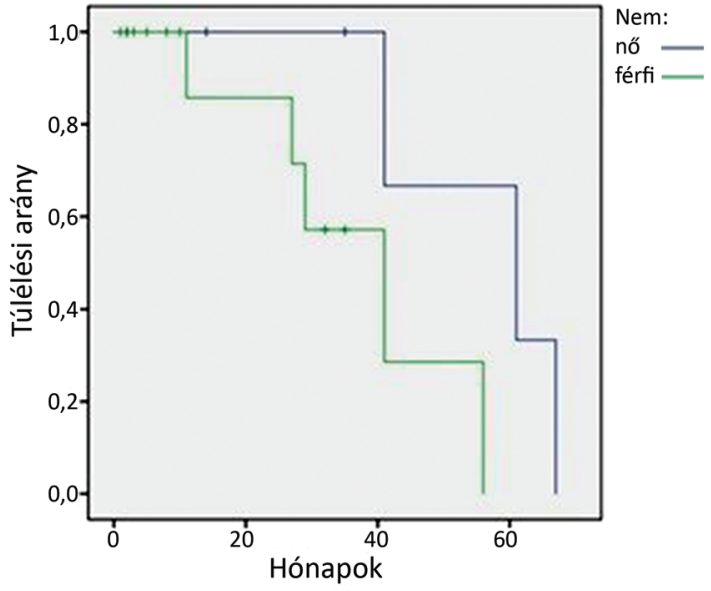

b)

5. ábra

Kaplan-Meier-diagramok. Az a) ábra a vizsgált betegek túlélési arányát ( $\mathrm{n}=34$ ), a b) ábra a vizsgált betegek ( $\mathrm{n}=34,13$ férfi, 21 nő $)$ nemek szerinti túlélési arányát mutatja. Az összesített görbe alapján a vizsgált populáció $50 \%$-os túlélése 3 év. A nemek tekintetében (lásd a b) ábrán) szignifikáns különbséget találtunk: a nők relatíve jobb prognózist mutattak (50\%-os túlélés, 5 év), mint a férfiak (50\%-os túlélés, 3 év) 


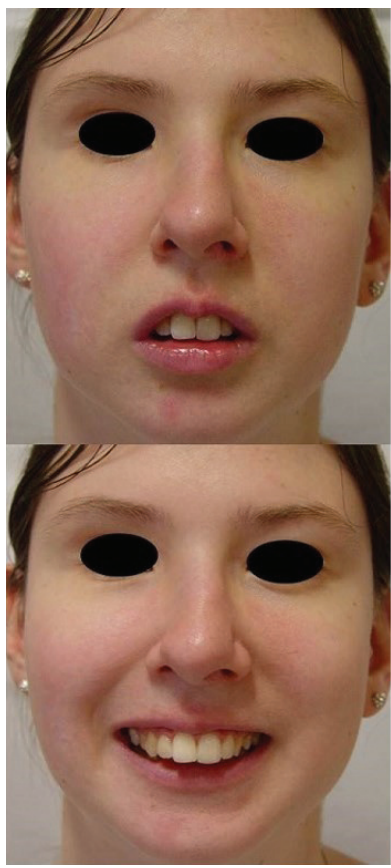

a)

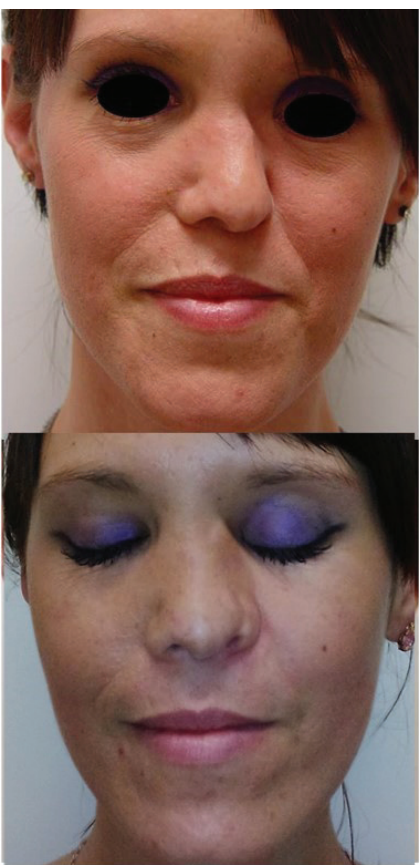

b)
6. ábra

a) Posztoperatív fotódokumentáció, melyen látszik az arcszimmetria. b) A mútét során eltávolított bal oldali orrcsont bordaporcos korrekciója (posztoperatív felvétel)

észlelt szövettani típusokból adódik (1. táblázat), férfiaknál a laphámcarcinoma $(\mathrm{n}=6)$ mellett nagy számban fordult elő melanoma malignum $(\mathrm{n}=4)$, mely szövettani típus a dignitását tekintve is az egyik legmalignusabb.

Annak bizonyítására, hogy az orrlégzési funkció nem károsodik a mütét során, akusztikus rinometriai vizsgálatokat végeztünk $\mathrm{kb}$. 1 évvel a mütétet követően, az irodalomban javasoltaknak megfelelően $[5,13]$. Az eredmények alapján az orrüreg beszúkülése nem volt észlelhető sem a külső, sem a belső „nasal valve” területén. Ennek megfelelően a betegek sem panaszoltak gátolt orrlégzést.

A „facial degloving” mütét után készített fotódokumentáción a mütött oldalon mimikai diszfunkciót nem észleltünk, az arc szimmetrikus maradt (6/a ábra). Egy esetben kényszerültünk a tumorosan infiltrált bal oldali orrcsontlemez eltávolítására (os nasale), a kialakult deformitást azonban az onkológiai kezelés befejezését követően bordaporccal korrigáltuk (6/b ábra) [5].

\section{Megbeszélés, következtetés}

Az első dokumentált maxillareszekciót Lizars végezte 1826-ban, de két évtizeddel később Fergusson írta le először Weber módszerének módosításával a manapság is alkalmazott klasszikus nyitott feltárást [1]. Az arc funkcionális és esztétikai integritásának fontosságára először Casson hívta fel a figyelmet 1974-ben, végül 1979-ben Conley és Price használta, majd publikálta a klasszikus „facial degloving” technikát, melynek alkalmazásakor a rosszindulatú arcüregi tumorokat a középarc lágy szöveteinek megemelésével távolítják el [4]. Az azóta eltelt évtizedek alatt a módszer több módosítását írták le [6-9, $14,15]$.

A szerzők rutinszerűen 2012 óta használják ezt a technikát orrmelléküreg-tumorok esetében. Súlyos szövődményt (infraorbitalis érzészavar, orrdeformáció, az orrüreg hegesedése és könnycsatorna-kanülálást igénylő könnyezés) nem észleltünk, míg a Weber-Fergusson-féle feltárással mütött betegeknél ezek mindegyike előfordult $[5,11,14,15]$. Betegeink zöme az orrnyálkahártya szárazságára, jelentős pörkösödésére és visszatérő enyhe orrvérzésre panaszkodik átmenetileg, melyek azonban lokális szerekkel (A-vitamin, pantenol) könnyen kezelhetők.

Közel az összes jóindulatú (invertált papilloma, neurinoma, adenoma, osteoma stb.) és szelektált esetekben a korai stádiumú rosszindulatú orrmelléküreg-tumort és az agyalapi régió jóindulatú daganatait transnasalis endoszkópos technikával távolítjuk el Klinikánkon, a nemzetközi ajánlásoknak megfelelően $[5,16]$. Véleményünk szerint ezek az endoszkópos technikák nagy szakmai tapasztalatot és gyakorlati jártasságot, továbbá drága eszközparkot igényelnek, melyek sok helyen jelenleg nem állnak rendelkezésre. Ezenkívül a tisztán endoszkópos mútéteknek vannak abszolút vagy relatív korlátaik: például az orbitaexenteratio, a sinus maxillaris vagy a sinus frontalis elülső falának vagy laterális recessusoknak az infiltrációja, infiltrált praemaxillaris lágy részek (periosteum, zsír, izom, bőr), dura- vagy agyi érintettség, infratemporalis/koponyaalapi terjedés, a carotis interna közelében elhelyezkedő tumor, a carotis interna vagy a sinus cavernosus inváziója stb. [5, 17].

A szerzők úgy vélik, hogy az általuk kifejlesztett módosított „facial degloving” technika a sebészi terápiás arzenál két végpontja (a minimálinvazív transnasalistransmaxillaris endoszkópos megközelítés és a transfacialis nyitott torzító mútét) között elhelyezkedve biztosítja az orrmelléküregi tumorok esetén a minimálinvazív, ablatív reszekciót rejtett hegekkel, jó esztétikai eredménynyel [5]. Ez utóbbi főként a következőknek tudható be: a nasalis vestibulum körkörös bőrmetszésének elhagyásával elkerülhető a gyakran leírt posztoperatív orrbemeneti heges szúkület mint leggyakoribb szövődmény. Továbbá a porcos orrcsúcs egysége megtartott marad, és az orrsövény horizontális vagy vertikális átvágásával a teljes porcos orrváz egyben mozgatható és az apertura piriformisról leválasztható, végül az oszteoplasztikus lebennyel együtt tökéletesen visszahelyezhető [5].

A bemutatott módszer egyszerüen kombinálható egy megkezdett endoszkópos mútéttel, vagy akár ki is válthatja azt a fentebb felsorolt problémák bármelyikének fennállása esetén. A posztoperatív eredmények a két módszer esetében összehasonlíthatók [5, 18, 19]. Ezen túlmenően, ha szükséges, akkor nyitott mütétté alakítása vagy egyéb mútéttel (például orbitaexenteratio) való kombinálása is lehetséges, akár a már zajló mútét közben. 
Véleményünk szerint a módosított „facial degloving” technika megfelelő alternatívája vagy kiegészítő módszere lehet a manapság egyre szélesebb körben alkalmazott minimálinvazív endoszkópos mútéteknek malignus orrmelléküregi tumorok esetében [5, 10, 20]. Lehetőséget biztosít továbbá az endoszkópos mútéti technikában kevésbé jártas sebészek vagy az ehhez szükséges mûszerparkkal nem rendelkező intézmények számára, hogy orrmelléküregi daganatban szenvedő betegeiket kezelni tudják. A két módszer kombinálásával egyértelmúen elérhető az onkológiai szempontból megfelelő mértékü radikalitás jó kozmetikai eredménnyel, látható hegek nélkül [5]. Előrehaladott esetekben (például orbitaérintettség) a módszer kombinálható nyitott technikával is [21]. Egyéb esetekben a külső feltárás mint első vonalbeli sebészi terápia a stigmatizáló bőrhegek és arcdeformitások miatt kerülendő.

Anyagi támogatás: A szerzők a kutatás és a kézirat elkészítése folyamán semmilyen anyagi támogatásban nem részesültek.

Szerzői munkamegosztás: Sz.-T. Á.: A közlemény megírása, a táblázat és a Kaplan-Meier-féle diagramok szerkesztése. V. G.: A kézirat szerkesztése. T. Z.: Az ábrák megrajzolása. I. L., R. L., B. Zs.: A kézirat véleményezése. A cikk végleges változatát valamennyi szerző elolvasta.

Érdekeltségek: A szerzőknek nincsenek érdekeltségeik.

Az ábrák a szerzők korábbi publikációjában (Vass G, Bella Z, Tóbiás Z, et al. Esthetically favorable surgical alternative for the removal of sinonasal malignant tumors The modified facial degloving technique. J Oral Maxillofac Surg. 2017; 75: 2272.el-2272.e10) szerepeltek már. A szerzők hozzájárultak az ábrák jelen publikációban való felhasználásához.

\section{Irodalom}

[1] Cracchiolo JR, Patel K, Migliacci JC, et al. Factors associated with a primary surgical approach for sinonasal squamous cell carcinoma. J Surg Oncol. 2018; 117: 756-764.

[2] Moya-Planaa A, Bresson D, Temam S, et al. Development of minimally invasive surgery for sinonasal malignancy. Eur Ann Otorhinolaryngol Head Neck Dis. 2016; 133: 405-411.

[3] Fergusson W. Operations of the upper jaw. In: Fergusson W (ed.) A system of practical surgery. 2nd edn. Lea and Blanchard, Philadelphia, PA, 1845; pp. 523-532.

[4] Conley J, Price JC. Sublabial approach to the nasal and the nasopharyngeal cavities. Am J Surg. 1979; 138: 615-618.
[5] Vass G, Bella Z, Tóbiás Z, et al. Esthetically favorable surgical alternative for the removal of sinonasal malignant tumors - The modified facial degloving technique. J Oral Maxillofac Surg. 2017; 75: 2272.el-2272.el0.

[6] Jaber JJ, Ruggiero F, Zender CA. Facial degloving approach to the midface. Oper Techn Otolaryngol Head Neck Surg. 2010; 21: 171-174

[7] Zaghloul AS, Nouh MA, Fatah HA. Midfacial degloving approach for malignant maxillary tumors. J Egypt Natl Canc Inst. 2004; 16: 69-75.

[8] Ferreira LM, Rios AS, Gomes EF, et al. Midfacial degloving. Access to nasal cavity and paranasal sinuses lesions. Braz J Otorhinolaryngol. 2006; 72: 158-162.

[9] Kitagawa Y, Baur D, King S, et al. The role of midfacial degloving approach for maxillary cysts and tumors. J Oral Maxillofac Surg. 2003; 61: 1418-1422.

[10] El-Banhawy OA, Shehab El-Dien Ael-H, Amer T. Endoscopicassisted midfacial degloving approach for type III juvenile angiofibroma. Int J Pediatr Otorhinolaryngol. 2004; 68: 21-28.

[11] Har-El G. Medial maxillectomy via midfacial degloving approach. Oper Techn Otolaryngol Head Neck Surg. 1999; 10: 82-86.

[12] Baumann A, Ewers R. Midfacial degloving: an alternative approach for traumatic corrections in the midface. Int $\mathrm{J}$ Oral Maxillofac Surg. 2001; 30: 272-277.

[13] Lindemann J, Leiacker R, Sikora T, et al. Impact of unilateral sinus surgery with resection of the turbinates by means of midfacial degloving on nasal air conditioning. Laryngoscope 2002; 112: 2062-2066.

[14] Jeon SY, Jeong JH, Kim HS, et al. Hemifacial degloving approach for medial maxillectomy: a modification of midfacial degloving approach. Laryngoscope 2003; 113: 754-756.

[15] Kim HJ, Kim CH, Kang JW, et al. A modified midfacial degloving approach for the treatment of unilateral paranasal sinus tumours. J Craniomaxillofac Surg. 2011; 39: 284-288.

[16] Meccariello G, Deganello A, Choussy O, et al. Endoscopic nasal versus open approach for the management of sinonasal adenocarcinoma: a pooled-analysis of 1826 patients. Head Neck 2016; 38(Suppl 1): E2267-E2274.

[17] Lund VJ, Stammberger H, Nicolai P, et al. European position paper on endoscopic management of tumours of the nose, paranasal sinuses and skull base. Rhinol Suppl. 2010; 22: 1-143.

[18] Fu TS, Monteiro E, Muhanna N, et al. Comparison of outcomes for open versus endoscopic approaches for olfactory neuroblastoma: a systematic review and individual participant data metaanalysis. Head Neck 2016; 38(Suppl 1): E2306-E2316.

[19] Saedi B, Aghili M, Motiee M, et al. Surgical outcomes of malignant sinonasal tumours: open versus endoscopic surgical approaches. J Laryngol Otol. 2014; 128: 784-790.

[20] Ikeda K, Suzuki H, Oshima T, et al. Midfacial degloving approach facilitated by endoscope to the sinonasal malignancy. Auris Nasus Larynx 1998; 25: 289-293.

[21] Browne JD, Messner AH. Lateral orbital/anterior midfacial degloving approach for nasopharyngeal angiofibromas with cavernous sinus extension. Skull Base Surg. 1994; 4: 232-238.

(Szalenko-Tőkés Ágnes dr., Szeged, Tisza Lajos krt. 111., 6725 e-mail: szalenko.tokes.agnes@gmail.com)

A cikk a Creative Commons Attribution 4.0 International License (https://creativecommons.org/licenses/by/4.0/) feltételei szerint publikált Open Access közlemény, melynek szellemében a cikk bármilyen médiumban szabadon felhasználható, megosztható és újraközölhetö, feltéve, hogy az eredeti szerző és a közlés helye, illetve a CC License linkje és az esetlegesen végrehajtott módosítások feltüntetésre kerülnek. (SID_1) 